História (São Paulo)

\title{
“O dia de amanhã”: A República nas páginas do periódico ilustrado O Mequetrefe, 1875-1889
}

\section{“The Morning”: The Republic on the pages of the illustrated periodical, O Mequetrefe, 1875-1889}

Aristeu Elisandro Machado LOPES*

Resumo: O periódico ilustrado O Mequetrefe iniciou sua circulação no Rio de Janeiro em 1875 e manteve suas atividades até janeiro de 1893. No transcurso de sua trajetória, os temas políticos se sobressaíram tratados em irreverentes ilustrações e em textos de opinião. Em suas páginas foram noticiadas as principais mudanças políticas ocorridas no Brasil Imperial, como a Abolição dos Escravos e o fim do Império com o advento republicano. O Mequetrefe publicou, ao longo de seus anos de atuação, notícias e opiniões sobre o ideário republicano difundido por seus adeptos na Corte. Já no final dos anos 1880, o jornal defendia a mudança de governo no Brasil com a República. O objetivo principal deste artigo é, portanto, averiguar quais as considerações deste periódico que foram dirigidas à questão republicana até a Proclamação da República. Outro assunto a ser tratado aqui é como a República - por meio do emprego das alegorias femininas e seus propagandistas - surgiu nas produções artísticas dos desenhistas e nas opiniões dos colaboradores do jornal, que igualmente se dedicavam ao humor e a sátira.

Palavras-chave: República. Imprensa ilustrada. Rio de Janeiro. Alegorias femininas.

Abstract: $O$ Mequetrefe, an illustrated periodical, was first published in Rio de Janeiro in 1875, and continued in circulation until 1893. In its history, political issues were dealt with through irreverent illustrations and commentaries. On its pages the main political changes during Imperial Brazil were announced, such as the abolition of slavery and the end of the Empire itself after the Declaration of the Republic. During its lifetime, O Mequetrefe published news and opinions on Republican ideas divulged

\footnotetext{
* Professor Adjunto I - Departamento de História e Programa de Pós-Graduação em História - Universidade Federal de Pelotas - Campus das Ciências Sociais - Rua Alberto Rosa, 154, CEP: 96010-770, Pelotas, Rio Grande do Sul, Brasil. Mestre e Doutor em História pela Universidade Federal do Rio Grande do Sul. E-mail: aristeuufpel@yahoo.com.br
} 


\section{Aristeu Elisandro Machado Lopes}

by its supporters at the Imperial Court. By the end of the 1880s the periodical defended changes in the government of Brazil. The main purpose of this article is to investigate which positions at that time were directed toward Republican matters until the Declaration of the Republic. Another issue to be addressed in this article is how the Republic - through female allegories and its enthusiasts - was represented in the artistic representations by cartoonists and in the opinions of the publication's collaborators, which likewise was dedicated to humor and satire.

Keywords: Republic. Illustrated press. Rio de Janeiro. Female allegories.

\section{Considerações iniciais}

O primeiro número do periódico O Mequetrefe foi lançado em janeiro de 1875 . O jornal foi uma iniciativa de Pedro Lima e Eduardo Joaquim Correa; este se tornou o único proprietário do jornal em 1879 e se manteria nessa condição até sua morte, em maio de 1891; a viúva assumiu os negócios do marido, colocando seu cunhado, José Joaquim Correa, no comando do jornal. Suas atividades somente se encerrariam em janeiro de 1893.

Ao longo dos anos de sua circulação o periódico contou com um número variado de colaboradores, como Olavo Bilac, Artur Azevedo, Henrique Lopes de Mendonça, Lúcio de Mendonça, Raimundo Correia, Filinto de Almeida e Lins de Albuquerque, este exercendo o cargo de diretor por um determinado tempo. Entre os caricaturistas, passaram pelo periódico Candido de Faria, Antonio Alves do Vale, Joseph Mill, Aluisio Azevedo, que mais tarde abandonaria os desenhos para se dedicar à literatura, e Antonio Bernardes Pereira Netto (LIMA, 1964, p.116). Netto permaneceu por dez anos ilustrando o periódico e se retirou para substituir Angelo Agostini na Revista Illustrada, após seu afastamento devido a uma viagem para Paris, em 1888 (BALABAN, 2005, p.48-51).

Já no primeiro ano de circulação, o periódico abordava em suas páginas a questão republicana que havia iniciado, de forma oficial, cinco anos antes com a fundação do Partido Republicano no Rio de Janeiro (BOEHRER, 2000, p.45). O arranjo do jornal no que toca às questões políticas foi evidenciado nos primeiros números do periódico. A redação afirmava "não somos republicanos... mas também não somos monarquistas. Em princípios políticos, que se prendam a formas de governo, assim como em questões de nacionalidade, nem queremos ser vistos, nem cheirados” (O Mequetrefe, 15/04/1875). Apesar da afirmação, o periódico publicou ilustrações, notícias e textos de opinião sobre os republicanos; no que se refere à parte ilustrada, aproveitou as alegorias femininas da República na 
“O dia de amanhã”: A República nas páginas do periódico ilustrado

O Mequetrefe, 1875-1889

composição de seus desenhos. Como a república surgiu nas páginas do periódico, sobretudo em suas produções artísticas, constitui o cerne que conduzirá esse artigo doravante.

\section{O Mequetrefe e a propaganda republicana no Império do Brasil}

Na composição de suas ilustrações, os desenhistas atuantes em $O$ Mequetrefe - assim como os demais da imprensa ilustrada do Rio de Janeiro - empregaram os símbolos republicanos inspirados nos modelos revolucionários difundidos, sobretudo, com a Revolução Francesa em 1789 e após a Primeira República na França em 1792 (AGULHON, 1979; AGULHON, 1989). Contudo, vale ressaltar, que os símbolos não surgiram nesse instante, de forma específica, mas foram retomados de outros momentos da história ou readaptados para circunstâncias novas (STAROBINSK, 1988, p.17-18). Além da alegoria feminina da República, o barrete frígio foi outro elemento simbólico que se destacou no cenário pós-revolucionário francês. Conforme Michel Vovelle (1997, p.177), foi nos primeiros dias da Revolução que a figura indistinta dos sans-culotte surgiu no meio da multidão reconhecida por sua roupa e pelo barrete. O recurso aos símbolos republicanos, contudo, era a melhor maneira para substituir a Monarquia francesa. No caso dos caricaturistas brasileiros, o uso das alegorias republicanas servia para a composição de sua sátira à Monarquia brasileira, uma vez que as duas formas de governo são consideradas adversárias; assim o emprego de elementos que as caracterizam - colocados contrapostos - configurava e remetia os leitores à sátira pretendida na composição dos desenhos. A alegoria Feminina da República foi o elemento desse conjunto que mais apareceu nas páginas dos periódicos, como em $O$ Mequetrefe.

Um exemplo de alegoria que criticava o Império apareceu na primeira página de O Mequetrefe, em 07 de outubro de 1875. A sátira, contudo, se dirigia a uma das instituições relacionadas à Monarquia, a Igreja Católica. A imagem mostra a alegoria feminina espremendo um de seus representantes (Figura 1). A alegoria não apresenta nenhuma identificação junto ao corpo; pressupõe-se que se trata daquela da liberdade, uma vez que é esta a palavra que identifica o líquido por ela espremido e que sai da boca do homem. Além de provocar o riso no leitor que aprecia a cena desenhada, a mensagem combativa também era evidente.

A alegoria é bastante simples; os traços de seu corpo e de suas vestes são tênues em relação ao fundo do desenho, o que lhe confere um aspecto fantasmagórico. À cabeça, embora o tracejado seja um tanto fraco, é possível identificar claramente o barrete frígio, ao passo que a face é delineada de forma a 


\section{Aristeu Elisandro Machado Lopes}

deixá-la jovial e delicada, se comparada com os traços do rosto do homem. Sua mão não traz nenhum dos outros atributos republicanos, mas ela é firme e segura com força a prensa da qual sairá, no final, a liberdade. Maurice Agulhon (1979, p.8) ao tratar do emprego das alegorias, dos símbolos e dos emblemas no caso francês, adverte que eles constituem imagens que correspondem a ideias abstratas como Liberdade, República, Revolução, França. A alegoria desenhada em $O$ Mequetrefe vai ao encontro dessa constatação, uma vez que trata de um desses ideais, embora empregada numa circunstância nova.

A legenda explicava a ação que se desenvolvia no desenho: "Até que lhe façam como a uva, segundo diz S. Agostinho: espremê-la para que produza alguma coisa de bom”. Quem estava sendo espremida era a Igreja e o algo de bom que apareceria era a Liberdade. O homem representa a Igreja e a

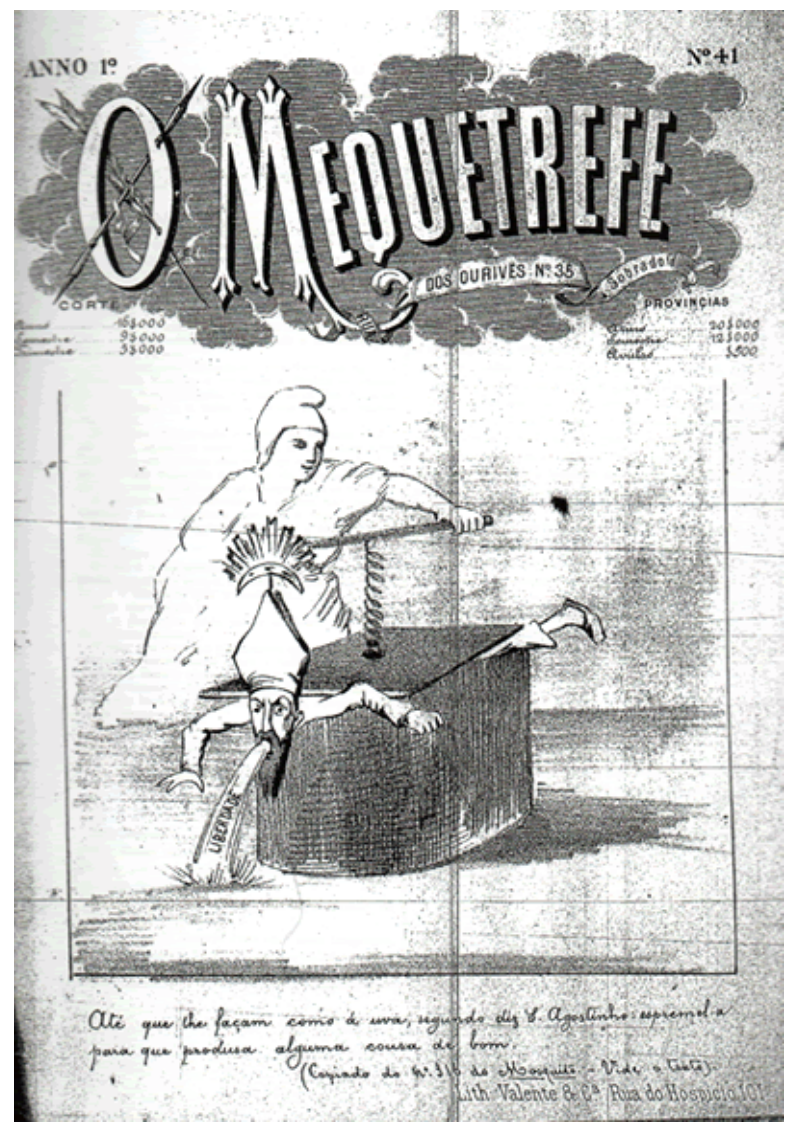

Figura 1: A Alegoria espremendo o bispo

Legenda: Até que lhe façam como a uva, segundo diz S. Agostinho: espremê-la para que produza alguma coisa de bom.

Fonte: O Mequetrefe, Rio de Janeiro, n.41, p.1, 07 out. 1875. Acervo: AEL-UNICAMP 
“O dia de amanhã”: A República nas páginas do periódico ilustrado

O Mequetrefe, 1875-1889

referência é feita por meio do emprego de um dos símbolos usados por membros da hierarquia da Igreja Católica, a Mitra. Assim, é possível que ele não seja um padre, e sim um bispo, visto que a este cargo eclesiástico cabe o uso deste chapéu alto e de pontas, símbolo do poder espiritual que é investido aos bispos, considerados representantes dos apóstolos na terra. O conjunto da imagem não tratava o ideário republicano: satirizava a Questão Religiosa.

Essa ilustração é apenas uma entre tantas outras veiculadas nesse periódico e em outros da Corte sobre o conflito (LIMA, 1963, p.238-246). No entanto, esse desenho é importante aos propósitos deste artigo devido à alegoria feminina que foi empregada para abordar a questão. O uso da alegoria não se referia diretamente às atividades republicanas, como era recorrente nos periódicos, ela foi adaptada para um contexto novo que considerava a Igreja como opressora, como um atraso, que emperrava o progresso do país e que, por isso, deveria ser “espremida”, acabando com o jugo da Igreja sobre o Estado. Em outras palavras, a separação entre a Igreja e o Estado representava a conquista da liberdade, a qual viria com a República.

Retornando à imagem, ela não revela o seu autor, ou melhor, não apresenta quem a reproduziu nas páginas de $O$ Mequetrefe, visto que é uma cópia de um desenho de Rafael Bordallo Pinheiro ${ }^{1}$, publicada em $O$ Mosquito, em 02 de outubro de 1875. A informação foi dada com a reprodução que revela se tratar de um desenho copiado do jornal congênere e remete o leitor para um texto explicativo na página dois. Em $O$ Mosquito, o desenho foi publicado menor, ao lado de outros que abordavam assuntos variados, sendo um deles a Questão Religiosa. Na reprodução publicada em O Mequetrefe, o artista deu destaque "para que ele dê mais na vista; queremos que ele avulte aos olhos dos nossos assinantes essa feliz prova que enceta o Mosquito” (A NOSSA PRIMEIRA..., out.1875, p. 2).

O jornal revelava, ainda, que o desenho concebido por Rafael Bordallo Pinheiro era inspirado em outro, publicado na França por H.Meyer. Embora concebida para satirizar a Igreja, o texto fazia uma relação com o debate republicano explicando que a "rapariga” que espreme o bispo: "é a própria liberdade, é a república do futuro” (A NOSSA PRIMEIRA.., out.1875, p. 2). Somente ela poderia acabar com o representante do "ultramontanismo retrógrado”, possibilitando a liberdade da qual o país estava apartado: “só a República pode salvar o Brasil das garras do ultramontanismo”2 (A NOSSA PRIMEIRA.., out.1875, p. 2).

A imagem permite algumas interpretações não só em relação ao posicionamento de $O$ Mequetrefe como também ao seu “comportamento”. Num primeiro momento, demonstra a circulação 


\section{Aristeu Elisandro Machado Lopes}

das ilustrações que eram concebidas num periódico e copiadas por outros artistas, atividade corriqueira no século XIX (SALGUEIRO, 2003, p.82). No caso dessa imagem, sua inspiração começou no desenho de Bordallo Pinheiro que, por sua vez, se guiou num artista francês. A reprodução ainda atesta que, num instante inicial, as relações entre os dois periódicos eram amistosas. Possivelmente, a cópia também serviu para dar as boas vindas ao colega caricaturista que acabava de chegar no Brasil.

Além de referendar a fonte da ilustração, o periódico incentivava ainda mais a campanha contra os bispos, dando notoriedade à causa com a veiculação de ilustrações que satirizavam abertamente os representantes da Igreja Católica. No final, ao revelarem que a alegoria feminina da liberdade é a República do futuro, acabaram fazendo referência aos republicanos. A solução seria a instalação de um governo republicano como a única forma de acabar com a subordinação do país perante a religião, aliança considerada um retrocesso. O texto encerrava afiançando que este era o pensamento colocado no desenho de Bordallo Pinheiro e compartilhado em $O$ Mosquito. No entanto, ao reproduzirem o desenho, acabavam igualmente enfatizando - talvez não propositadamente - a campanha dos republicanos.

Apesar das afirmações, o jornal seguiria sendo relacionado à propaganda republicana, possivelmente por causa das ilustrações que publicava. Essa situação foi enfrentada pelo periódico que apresentava uma posição ambígua: se declarava não republicano na parte textual e utilizava a simbologia republicana em suas ilustrações. Essa dicotomia seguiu em suas páginas ao longo de seu primeiro ano, como exemplificam o texto e a imagem que serão analisados na sequência.

“O Mequetrefe ou gato por lebre republicano” esse foi o título de um artigo veiculado na Gazeta de Notícias, conforme atestava o periódico ilustrado em sua resposta publicada em 28 de outubro de 1875. Após agradecer aos colegas que "aceitaram com a mais alegre imparcialidade” o exemplar do jornal enviado à redação, publicaram a nota dedicada a eles. Não foi somente a "provável” aproximação do periódico com os republicanos que foi criticada; os desenhos no geral e os responsáveis também foram desapreciados: “Os redatores dessa folha desilustrada devem ter realmente muita fome. Não se pode explicar de outro modo a maneira por que apresentam sempre no meio dos bonecos, aliás bem mal desenhados, um bonnét (sic) frígio como um cometa que ameaça a nossa tranquilidade monárquica” (O MEQUETREFE..., out.1875, p. 3). A Gazeta, conforme essa passagem publicada em $O$ Mequetrefe, acusava o periódico de receber pagamentos em troca da veiculação de símbolos republicanos em suas páginas. 
“O dia de amanhã”: A República nas páginas do periódico ilustrado

O Mequetrefe, 1875-1889

A resposta dada em sua defesa não veio pelas ilustrações, mas numa Epístola em versos rebatendo as acusações. A réplica, no entanto, não abordou o posicionamento político do periódico; o texto acusava, num primeiro momento, que o seu crítico assinou o jornal e não pagou:

Ou me dê o meu recibo,/Ou me pague a assinatura;/Do contrário não arribo/E a tal fome sempre dura./Há tantos meses que espero/Que já quase desespero./Até já sinto arrelia,/E não tarda que publique,/Embora bem mal fique,/Que ao doutor... dou anistia. (O MEQUETREFE..., out. 1875, p. 3).

O articulista, ao responder às críticas, não defendeu seus "bonecos”. Na sequência da resposta, assegurava que ele foi ao escritório do periódico sem ter sido convidado, atitude de quem "acompanha a cozinheira nos banquetes dos fidalgos” (O MEQUETREFE..., out. 1875, p. 3). Ainda, chamava os redatores da Gazeta de Notícias de “galgos [cães] cujo ofício é só lamber”. É possível considerar que, ao responder às críticas, o periódico acusava o seu algoz de ser subserviente e simpático da Monarquia, que ele era um bajulador - “lambedor” - dos monarquistas. Por fim, o periódico perguntava:

Com que então tem muita fome/ Os redatores, não é?/ E o meu doutor se consome/ Com o cometa e o bonnét?/ E os considera ciganos,/ Terríveis republicanos,/ Conspirando contra o rei?/ E só tem papel de embrulho/ Pra fazer tanto barulho,/ Assustando a farta grey? (O MEQUETREFE..., out. 1875, p. 3).

A primeira indagação é sobre qual a fome que os redatores eram acusados, provavelmente uma fome republicana, motivo pelo qual o “doutor” da Gazeta, um monarquista, se consumia preocupado com o emprego dos terríveis símbolos, os quais conspiravam contra o rei. Contudo, o final parece indicar ser a preocupação exagerada do colega, uma vez que ele, em suas acusações, chamou o periódico de “papel de embrulho” e isso, na visão de O Mequetrefe, não é capaz de fazer tanto barulho. Em outras palavras, o periódico assegurava que os seus desenhos, mesmo que apresentassem barretes frígios e alegorias femininas, não seriam suficientes, sozinhos, para ocasionar uma mudança nos rumos da política brasileira. Ainda, o periódico já referendara que sua posição não era republicana e para que uma mudança efetiva ocorresse seriam necessários alguns arranjos políticos, dos quais a República poderia ser uma solução futura. Esse é o tema da ilustração veiculada no mesmo número em que as acusações foram rebatidas.

A ilustração ocupou as páginas centrais em $O$ Mequetrefe e foi produzida ambientada num quarto (Figura 2). A personagem central está alocada à direita, na página cinco; ela é uma alegoria 
feminina que alude à Monarquia, deitada numa cama e rodeada de outros personagens. Na parte direita do desenho, que corresponde à página quatro, está uma outra alegoria feminina, trata-se da relacionada à República. A alegoria da Monarquia é uma figura envelhecida e possui uma expressão de dor e de morte, enquanto sua oponente foi concebida com traços joviais.

Ao redor da cama, alguns personagens e objetos dão ao desenho um aspecto de desespero, causado pela morte iminente da qual se aproxima a Monarquia. Aos pés da cama, uma mesa identificada como “jesuitismo” apresenta sob o seu tampo alguns frascos identificados: “morcegos”, “água de Lourdes” e “corrupção” medicamentos ministrados à Monarquia, que mais denotavam a causa do que o tratamento da sua doença. Não somente os remédios eram a origem das mazelas, como

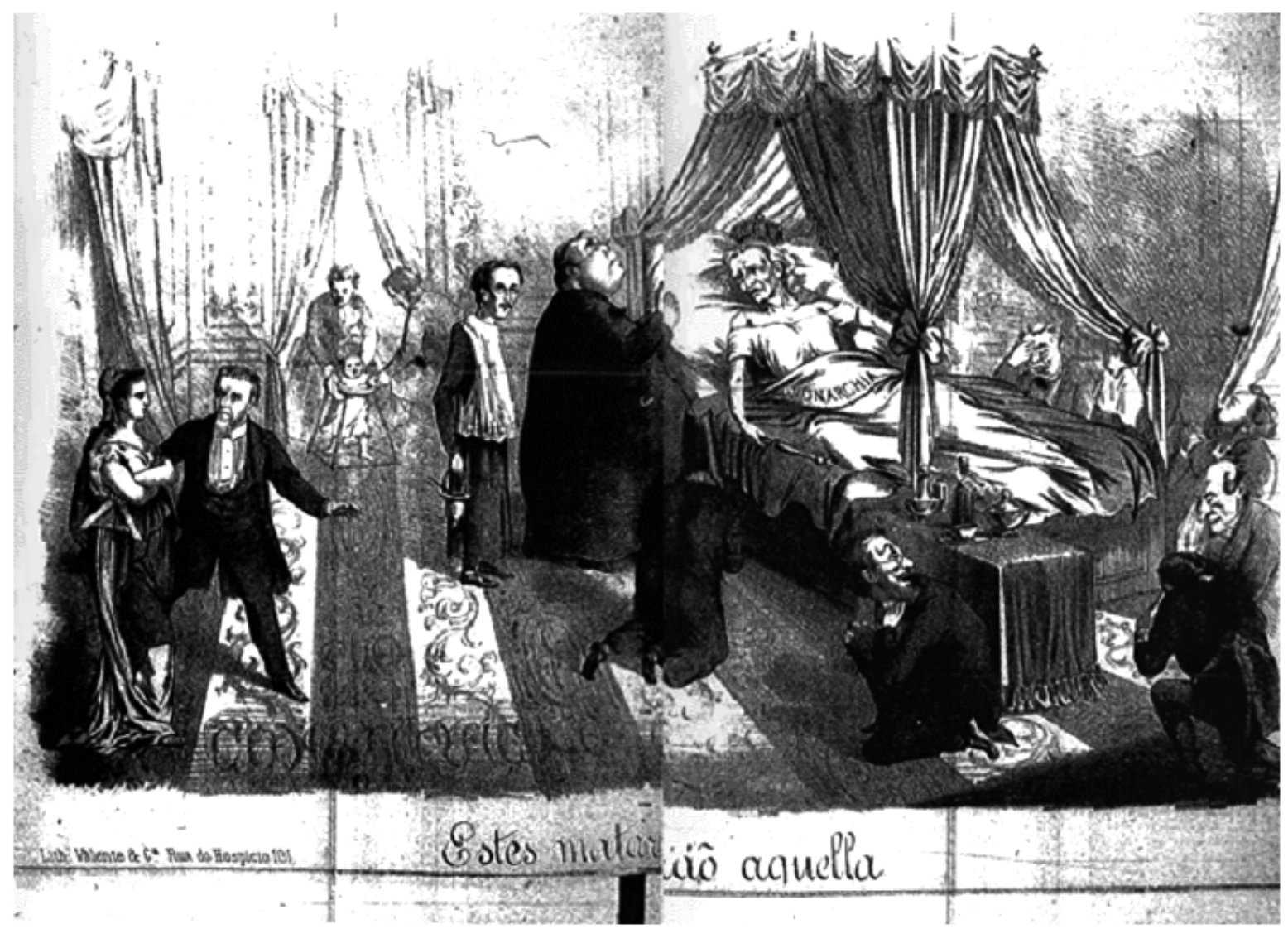

Figura 2: A morte da Monarquia Legenda: Estes matarão aquela.

Fonte: O Mequetrefe, Rio de Janeiro, n.44, p.3-4, 28 out. 1875. Acervo: AEL-UNICAMP

também a presença da Igreja, conforme assegurava a inscrição colocada na mesa. Além disso, três membros da Igreja Católica aparecem no desenho; o primeiro, com mais destaque, está à cabeceira, 
“O dia de amanhã”: A República nas páginas do periódico ilustrado

O Mequetrefe, 1875-1889

com as mãos em posição de oração e o rosto erguido aos céus pede a salvação da Monarquia; o outro, pelo contrário, está ajoelhado e cabisbaixo e, igualmente, reza pela saúde monárquica enquanto o terceiro, um sacristão com um turíbulo, assiste à cena com certa indiferença, observando o padre.

Os demais personagens que estão na volta da cama são, provavelmente, membros dos partidos políticos. Na outra ponta da cabeceira está o Duque de Caxias, presidente do Conselho de ministros do Império, posto que ocupava havia poucos meses, em 1875, como representante do Partido Conservador. Próximo à mesa, agachado e observando os demais homens, está Gaspar Silveira Martins, membro de grande expressão do Partido Liberal. A posição atribuída a ele no desenho é diferente daquela dada aos demais que estão no entorno da cama. Enquanto estes apresentam expressões de comoção, como o Duque de Caxias que ampara o rosto com a mão, e de súplicas como dos outros três; ao político liberal foi dado um ar zombeteiro. Ele parece rir da situação ao observar o desespero dos demais que eram representantes do Partido Conservador, já que com o possível restabelecimento da saúde monárquica poderia ocorrer uma reforma no poder e ele, ou o seu partido, alcançaria a Presidência do Gabinete.

Antes que isso acontecesse seria necessário salvar a própria Monarquia e, no caso de uma “morte”, quem assumiria o poder? A resposta está colocada na outra extremidade do desenho e sugere duas alternativas. A primeira está indicada no fundo do desenho e trata da herdeira do trono do Brasil, a Princesa Isabel. Colocada ao lado do marido, o Conde d'Eu, e do primeiro filho do casal, Dom Pedro, nascido em 1875. Isabel assumiu o trono brasileiro como Regente durante a primeira viagem internacional do Imperador, em 1871, o que se repetiria em outras duas ocasiões, também motivado por viagens internacionais de Dom Pedro II. A passagem de Isabel pelo trono do Império brasileiro era vista como uma preparação ao terceiro reinado; contudo, essa situação não era consensual e gerava posições contraditórias. Entre os problemas colocados ao reinado de Isabel estavam as suas relações com a religião. Considerada uma beata, interveio a favor da anistia dos bispos na Questão religiosa, o que lhe ocasionou impopularidade (DAIBERT JUNIOR, 2004, p.86-87). O outro, estava na nacionalidade do marido, visto como um estrangeiro, um intruso, opinião que somente aumentaria ao longo dos anos, tornando o príncipe uma figura bastante impopular (SCHWARCZ, 1998, p.432-433). Na ilustração de $O$ Mequetrefe nenhuma referência satirizava o casal. Eles aparecem nos desenhos como os substitutos da Monarquia adoentada apesar de estarem, naquele momento, com a sua atenção voltada para o filho. 


\section{Aristeu Elisandro Machado Lopes}

A outra sugestão apontada pelo periódico é a alternativa republicana, representada pela Alegoria feminina da República. Ela conversa com o deputado Joaquim Saldanha Marinho, que parece querer levá-la mais próximo da cama para que veja o estado lastimável em que se encontra a Monarquia. Contudo, a alegoria se coloca um tanto resistente, sua expressão é séria ao observar todo o cenário que o seu campo de visão lhe proporciona. Além do barrete frígio, um outro elemento foi colocado numa de suas mãos, um esquadro com a palavra "Igualdade”. Provavelmente o emprego de um símbolo caro aos maçons foi utilizado para espezinhar os representantes da Igreja Católica, em especial, no momento em que a Questão Religiosa ainda era discutida. Além disso, a colocação de Saldanha Marinho também não foi aleatória. Ele escreveu uma série de crônicas publicadas no Jornal do Commércio contra a igreja com o pseudônimo Ganganelli e era Grão-mestre da Maçonaria, ou seja, a presença de Saldanha Marinho foi outra forma do periódico se opor aos representantes eclesiásticos relacionados com a Monarquia.

Outra leitura da ilustração pode ser feita tomando-se por base uma provável "articulação republicana” em relação à alegoria, Saldanha Marinho e a posição que ambos ocupam no desenho. Enquanto a Monarquia estava prestes a morrer, os republicanos se organizavam para assumir o poder. A legenda atestava que "estes matarão aquela”, numa alusão às relações entre a Igreja e o Estado e as divergências entre os partidos Conservador e Liberal. Concomitante, os republicanos apenas observavam a bancarrota do Império e aguardavam o momento certo para agir e, durante a espera, a República contava com o desempenho de seus signatários nas atividades da campanha, entre os quais, Saldanha Marinho.

Ao longo de seu primeiro ano $O$ Mequetrefe abordou questões republicanas em suas páginas, mas sempre se colocando como um órgão não defensor da causa. Declarações afirmando sua posição foram constantes na mesma medida em que as alegorias ou barretes frígios apareceram nas ilustrações; a resposta enviada à Gazeta e a alegoria da morte da Monarquia são exemplos dessa situação e também denotam o tom ambíguo do jornal. Em outras palavras, enquanto asseguravam na parte textual que não professavam do ideário republicano, suas ilustrações indicavam um tom simpático em relação aos republicanos. Contudo, é possível que antes do emprego da simbologia republicana como uma forma de propagar os ideais, o periódico tenha se valido dela para satirizar a Monarquia ou então para atacar a Igreja. Esta hipótese é bastante significativa ao se verificar a última ilustração que apresenta a alegoria portando um esquadro e colocada ao lado de um dos membros mais importantes da Maçonaria no Brasil e severo crítico da união entre a Igreja e a Monarquia. George Boehrer está correto ao afirmar 
“O dia de amanhã”: A República nas páginas do periódico ilustrado

O Mequetrefe, 1875-1889

que $O$ Mequetrefe sempre demonstrou "pouco respeito pelo governo"; já sua posição "abertamente republicana” (BOEHRER, 2000, p.73), foi amadurecida ao longo dos anos de circulação, como será constatado nas páginas seguintes.

Outras duas ilustrações que abordaram a temática republicana foram veiculadas no periódico, no ano de 1879. A primeira ilustração foi publicada em 12 de abril de 1879 e mostra a figura de um índio representando o Brasil (Figura 3).

O uso de figuras indígenas foi comumente realizado pelos caricaturistas do século XIX, numa referência ao Império. O índio foi empregado com maior ênfase por Henrique Fleiuss na Semana Illustrada (1860-1876) e por Angelo Agostini na Revista Illustrada (1876-1888) (TEIXEIRA, 2001, p.25). Já o índio que surge em $O$ Mequetrefe não é o Brasil na sua atualidade, ou seja, não é o Brasil da Monarquia, ele é uma alusão ao país no futuro, à República, que renascerá. A ressurreição do índio o apresenta com um adorno, um barrete frígio à cabeça, o que faz referência a um governo republicano no lugar do atual, monárquico.

Essa ilustração de Pereira Netto ${ }^{3}$ não se refere somente ao Brasil, representado pela figura do índio, como também remete à crença defendida pela Igreja Católica em relação à ressurreição de Jesus Cristo. Para complementar essa comparação o caricaturista colocou no índio cabelos longos e levemente desgrenhados, semelhante à imagem comumente difundida de Cristo. Ao reaparecimento do índio, dotado do atributo republicano, pereciam os representantes do poder Monárquico colocados no primeiro plano do desenho, caídos, perante a figura que ascende. Além de Dom Pedro II, outros políticos importantes estão no desenho, vestidos de soldados romanos como os algozes que crucificaram Cristo. Entre eles está, novamente, o Duque de Caxias, que havia deixado a presidência do Conselho de Ministros em 1878, a qual estava ocupada pelo liberal João Lins Vieira Cansanção de Sinimbu. Completam a ilustração nuvens colocadas ao fundo que acompanham a ascensão do índio e dois anjos que seguram a pedra que fechava a entrada do seu túmulo.

A ilustração do periódico fazia referência a uma possível instalação de uma República no Brasil, que se inspirasse na independência norte-americana; a legenda, além de assegurar esse modelo, anunciava o tom premonitório dos desenhos: “Daqui há anos ele, como novo Cristo, ressurgirá dos mortos e subirá até a altura dos Estados Unidos e trabalhará para a unificação dos povos, pela remissão da miséria, pelo trabalho e extinção da ignorância pela instrução”. Uma possibilidade para a concretização das esperanças republicanas pode ser vista na colocação do Duque de Caxias, como 
membro do Partido Conservador, afastado do poder depois de anos. A chegada dos liberais poderia ser uma chance para as mudanças, como as citadas na legenda, começarem a acontecer. O caricaturista de O Mequetrefe estava inspirado na produção de desenhos premonitórios em relação ao futuro do Brasil. Além da ilustração que mostrava a ressurreição do país como republicano, outra imagem apresentava igualmente a temática republicana vista como um governo vindouro.

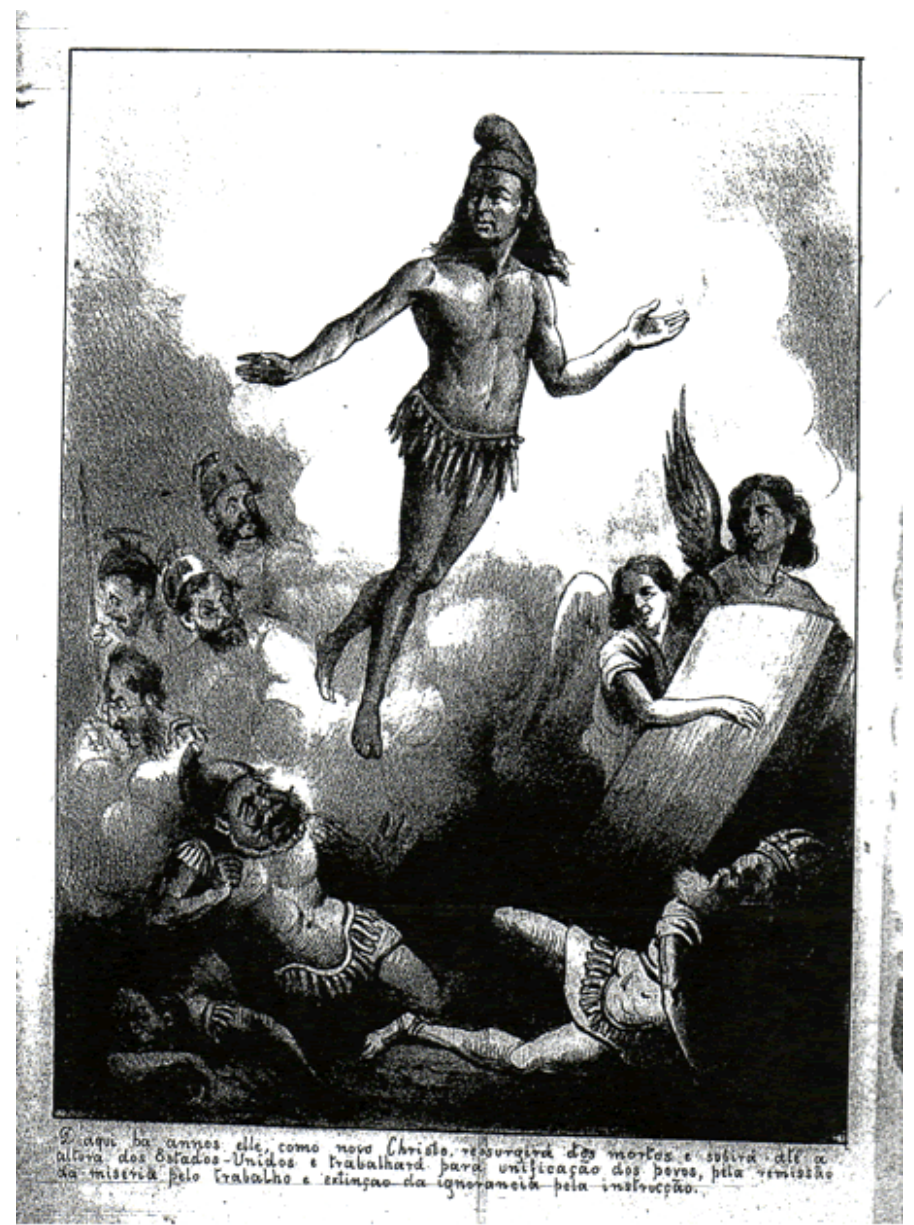

Figura 3: A ascensão do índio Brasil

Legenda: Daqui há anos ele, como novo Cristo, ressurgirá dos mortos e subirá até a altura dos Estados Unidos e trabalhará para a unificação dos povos, pela remissão da miséria, pelo trabalho

e extinção da ignorância pela instrução.

Fonte: O Mequetrefe, Rio de Janeiro, $\mathrm{n}^{\circ}$ 163, p.8, 12 abr. 1879. Acervo: AEL-UNICAMP.

Na ilustração publicada, em 14 de junho de 1879, surge uma alegoria feminina da República (Figura 4). Esta foi a primeira, assim identificada explicitamente, desde o início da circulação do periódico, que até então denominava suas alegorias por aquelas relativas à liberdade ou apenas sugeria 
“O dia de amanhã”: A República nas páginas do periódico ilustrado

O Mequetrefe, 1875-1889

se tratar da República. Nesta ilustração a ideia republicana é mais clara, ou seja, “O dia de amanhã” é associado com a questão republicana conforme a inscrição "República” colocada na bandeira que a alegoria carrega. A frase abaixo do título colocava que “Acreditamos que o estado atual dos negócios públicos preparam-nos este dia”. Não há nenhuma informação remetendo o leitor para um texto que explicasse a importância daquele dia. Na crônica publicada na página dois, era comentado um conflito ocorrido no Largo do Paço, no qual ficava o Paço Imperial (atual Praça XV) que "transformou-se em campo de batalha”. Possivelmente, a ilustração seja uma alusão à desordem. Conforme foi narrado no texto, a confusão envolveu moradores do Rio de Janeiro e os ministros do Império. Ao Presidente do Conselho, Sinimbu Cansanção, por exemplo, foram dedicadas "palavras amáveis a fazer corar um frade de pedra” (O Mequetrefe, 14. jun. 1879, p.2), referência irônica aos prováveis xingamentos dirigidos a ele, que as ouviu “sem pestanejar”. Em auxílio aos ministros veio uma chuva que obrigou os “cidadãos desta mui pacífica e leal cidade de São Sebastião deixarem todos aqueles instintos belicosos” ( $O$ Mequetrefe, 14. jun. 1879, p.2).

O jornal não colocava maiores explicações sobre esse provável conflito, ocorrido no Largo do Paço. Uma possibilidade para o alvoroço pode ser vista numa suposta reunião entre o Imperador e os seus ministros e quando da chegada destes - ou na saída - os transeuntes presentes tenham, como sugere o periódico, protestado com “palavras amáveis”. No entanto, o que convém considerar nessa imagem é a sua veiculação e os detalhes de sua confecção.

Num primeiro momento, é preciso ponderar que se trata de uma alegoria feminina da República que se assemelha a outra, mais conhecida, trata-se da Liberdade Conduzindo o Povo de Eugène Delacroix ${ }^{4}$. Esta pintura foi concebida por ele em 1831 e fazia referência à Revolução de 1830, ocorrida na França, que resultou na queda do Rei Carlos X e na elevação de Luis Felipe ao poder (HOBSBAWM, 2007, p.169). É possível considerar, valendo-se dessa assimilação, que Pereira Netto era conhecedor do mundo das artes na Europa, em especial, a pintura francesa. Assim como outros colegas, como Angelo Agostini que confeccionou alegorias femininas que também lembram aquela de Delacroix, Netto produziu desenhos com temática republicana que envolvia alegorias femininas.

A alegoria de Netto está num lugar de destaque na ilustração, ocupando o seu centro; seu perfil é destacado no contraste entre a luz que a ilumina, a partir de cima (igual àquela de Delacroix) e a escuridão que predomina em quase todo o resto do quadro que delimita o desenho. Ela está armada, 
carregando uma espada em riste no braço direito enquanto no outro traz a bandeira "República" que

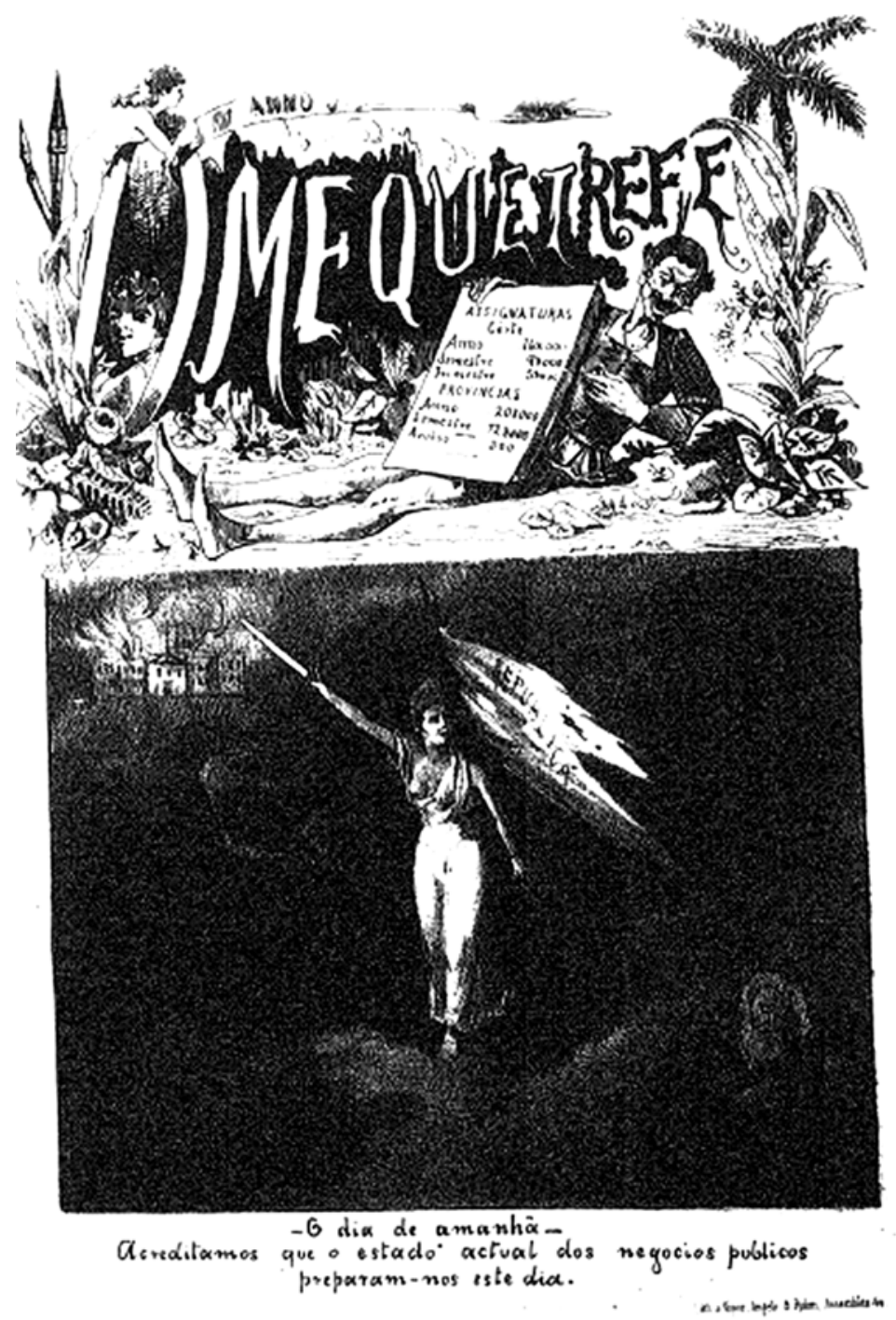

Figura 4: A alegoria feminina da República

Legenda: O dia de amanhã - acreditamos que o estado atual dos negócios públicos preparam-nos este dia.

Fonte: O Mequetrefe, Rio de Janeiro, nº171, p.1, 14 jun. 1879. Acervo: AEL-UNICAMP.

está com sua parte final esfarrapada. A semelhança com a alegoria da tela de Delacroix é notória. Netto, contudo, mudou o braço que levava a bandeira e o fuzil por uma espada. O barrete frígio, os pés descalços, as roupas rasgadas e um dos seios desnudos completam sua apresentação e são características parecidas com as apresentadas por aquela do pintor francês.

Vale considerar que a alegoria de Netto não é uma cópia daquela pintada por Delacroix décadas antes. Entretanto, as semelhanças permitem considerar que ela pode ter sido uma inspiração para o 
“O dia de amanhã”: A República nas páginas do periódico ilustrado

O Mequetrefe, 1875-1889

artista brasileiro ao confeccionar seu modelo de alegoria. Outra similitude visível entre a ilustração e a pintura é o prédio incendiando ao fundo. Em Delacroix, o que está queimando é a Igreja Notre Dame de Paris; na ilustração é possível inferir, com base no texto acima comentado, a possibilidade de que o prédio incendiado seja o Paço Imperial. As demais figuras humanas que aparecem na pintura de Delacroix foram todas retiradas da ilustração - no desenho de Netto, a alegoria foi colocada "solta” no meio de uma imensidão escura. No entanto, apenas uma pessoa figura na parte inferior da ilustração, a qual lembra a posição do soldado morto que jaz à direita na pintura de Delacroix. O corpo do soldado foi substituído pelo Imperador Dom Pedro II que, devido à escuridão do desenho, parece estar deitado. Ele está amparando o rosto com a mão, num tom de desolação, numa referência à ação que se passa: o triunfo da República e a destruição de seu palácio.

Ao longo dos anos de circulação, a temática republicana continuou aparecendo em $O$ Mequetrefe; e seu posicionamento foi se tornando mais nítido. Um exemplo é encontrado no texto publicado em 10 de julho de 1883, intitulado “14 de julho”. A notícia era sobre as comemorações que seriam realizadas pela Colônia Francesa no dia 14 de julho, aniversário da Revolução Francesa; também comentavam um livro alusivo à data, História da Revolução Francesa de Ernesto Hamel. No fim, declaravam que "nós também cumprimentamos a França com o nosso barrete frígio. Ah! Porque não chega até nós os reflexos daquele grande sol” (14 de julho..., jul. 1883, p. 2). Em 1889, o ano do Centenário da Revolução Francesa, $O$ Mequetrefe também publicou um texto comemorativo ressaltando que as festividades não se restringiam somente “as brilhantes páginas da história da França, como na história de todos os povos, até onde poderiam alcançar os enebriantes raios do sol da liberdade” (Homenagem à República..., jul. 1889, nº 481, p. 2), incluindo, entre eles, os americanos. O “espírito” republicano parece ter tomado O Mequetrefe de forma definitiva nos últimos anos do Brasil Império, sobretudo a partir da Abolição dos Escravos, em 1888. Essa condição não ficou restrita somente ao exemplo do periódico, ela faz parte de um contexto de politização da sociedade fluminense na década de 1880, em especial nos anos de 1888 e 1889. Conforme aponta Maria Tereza Mello (2007, p.11): "O que ocorreu na década de 1880, foi a ampliação do espaço público através de associações, conferências, imprensa, livrarias, confeitarias, clubes, mobilizações populares, etc”. É possível concordar com a afirmação de George Boehrer, anteriormente comentada, sobre a posição do periódico, todavia, o posicionamento favorável foi feito lentamente, passando de simpático a defensor da causa republicana. 


\section{Aristeu Elisandro Machado Lopes}

Ao longo de alguns números de 1888, foram frequentes as homenagens aos propagandistas republicanos, todos homens, na primeira página do periódico. A “Galeria Republicana” foi inaugurada pelo periódico com uma homenagem a Antonio da Silva Jardim (n.459), Rangel Pestana (n.460), Quintino Bocaiúva (n.461) Francisco Glycério de Cerqueira Leite (n.462), José Lopes da Silva Trovão (nas páginas 4 e 5 do número 463), Barata Nunes Ribeiro (n.464), Alexandre Stockler (n.466), Monteiro Manso (n.468), Nilo Peçanha (n.469), Gualter Martins (n.471) e José Joaquim Ferreira Rabello (n.477).

Todos os retratos eram acompanhados por pequenos textos que exaltavam as qualidades políticas e/ou republicanas de seus homenageados na assim chamada “Galeria Republicana”: “É nosso propósito continuar a dar ao público retratos e biografias de todos os republicanos brasileiros merecedores do aplauso e da maior consideração” (Galeria Republicana..., dez. 1888, n 466, p.2). Os dois últimos - Gualter Martins e José Joaquim Ferreira Rabello - receberam distinção por terem devolvido seus títulos monárquicos e se alistarem ao Partido Republicano. Sobre o primeiro atestavam que seu ato era digno dos aplausos daqueles que "sentem em seu peito pulsar um coração verdadeiramente patriótico” (MARTINS, fev. 1889, nº 471, p. 3). O outro renunciou ao título de Barão do Serro "para incorporar-se aos verdadeiros brasileiros que formam hoje o simpático partido nacional” (RABELLO, maio 1889, nº477, p.2).

O Mequetrefe iniciou o ano de 1889 comemorando o seu $15^{\circ}$ aniversário. No texto que celebravam a data, salientavam que o periódico foi mantido sem a proteção de nenhum governo, que sua redação continuava fiel ao seu programa. Portanto, por essas razões, o periódico continuava merecendo do seu público honra e dedicação. Na continuação destacavam as principais causas defendidas pelo jornal:

O amor com que sempre defendemos a questão abolicionista ainda deve achar-se bem claro na memória dos nossos concidadãos é o nosso apoio claro, franco e decidido a ideia da democracia brasileira foi sempre por nós sustentada desde o dia que tivemos a honra de aparecer ao público. Continuando, pois, na defesa da ideia que hoje agita-se em todo o país, entendemos cumprir o nosso dever (O Mequetrefe, jan. 1889, nº 468, p.2).

O texto tornava clara a posição escolhida pelo jornal e que vinha sendo apresentada nos seus últimos números. Se antes combateram a escravidão em prol da democracia brasileira, agora era 
“O dia de amanhã”: A República nas páginas do periódico ilustrado

O Mequetrefe, 1875-1889

chegada a hora de uma nova batalha por ela, defendendo a ideia que se agitava por todas os cantos do Império, essa ideia era a República. Reforçando sua campanha foi publicada, neste mesmo número, uma nota sobre outra comemoração: o Centenário da Revolução Francesa, apontado como a "data mais

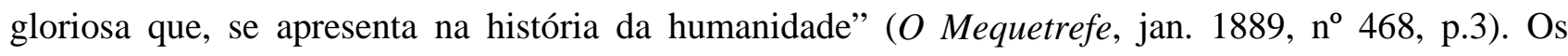
aniversários da Revolução já foram comentados em anos anteriores, como já verificado; este apresentava um tom mais enfático sobre o assunto, destacando a atuação do povo francês que “inspirado nas sublimes doutrinas da verdade e da justiça” (O Mequetrefe, jan. 1889, n 468, p.3) se libertaram da subjugação que os levava ao rebaixamento social imposto por um poder despótico. $O$ Mequetrefe, ao saudar o aniversário, declarava que sua existência se prendia à "grande revolução de 89”, na França, uma vez que foi ela que plantou alto o estandarte onde se encontra estampada "a concentração divina do nosso ideal”.

Tudo caminharia, conforme a óptica do periódico, para o fim da Monarquia e que os dias do Império do Brasil estavam contados. Dom Pedro II chegou a ser considerado “moralmente morto" numa de suas crônicas (Chronica?..., mar. 1889, n 474, p.2). E ao tratar da crise política do Império que levaria à queda do Gabinete de João Alfredo, substituído por Afonso Celso, o Visconde de Ouro Preto, o periódico colocava em sua primeira página uma alegoria feminina da República, como a responsável pela “apoteose final da atual crise política” (Figura 5).

A ilustração mostra a alegoria retornando para dentro do palácio, possivelmente uma das sedes do Império do Brasil, para buscar mais objetos que seriam jogados fora. Na calçada já estavam no chão alguns deles, como o trono do Império (que está com a cruz que encima a coroa colocada ao alto da cabeceira quebrada). Um dos pés do trono, que lembram garras, também está quebrado. Jazem, ainda, a coroa imperial, o manto usado em ocasiões especiais por Dom Pedro II e o cetro que está partido.

É possível verificar que a alegoria emana de seu corpo vários fachos de luz, projetados para cima dos objetos caídos; ela foi desenhada com o barrete frígio e desprovida de suas armas, demonstrando que a apoteose republicana aconteceria sem ser necessário que batalhas fossem travadas. Ela somente precisava da força de seus braços, e dos republicanos, para jogar fora as insígnias imperiais e dar ao Brasil um novo caminho - “o dia de amanhã” - iluminado por seus ideais.

Essa ilustração permite uma observação importante. Se no primeiro ano do periódico - 1875 - o ideário republicano não foi abordado de uma forma explícita (apesar de motivar críticas na Gazeta de 
Notícias e de veicular alegorias) agora - 1889 - ele passou a ser um dos conteúdos mais abordados e defendidos. A alegoria foi comentada num texto ressaltando que “A República desponta já no horizonte da nossa pátria, é necessário não recuarmos um só passo da luta em que nos achamos francamente combatendo em favor da democracia brasileira”.

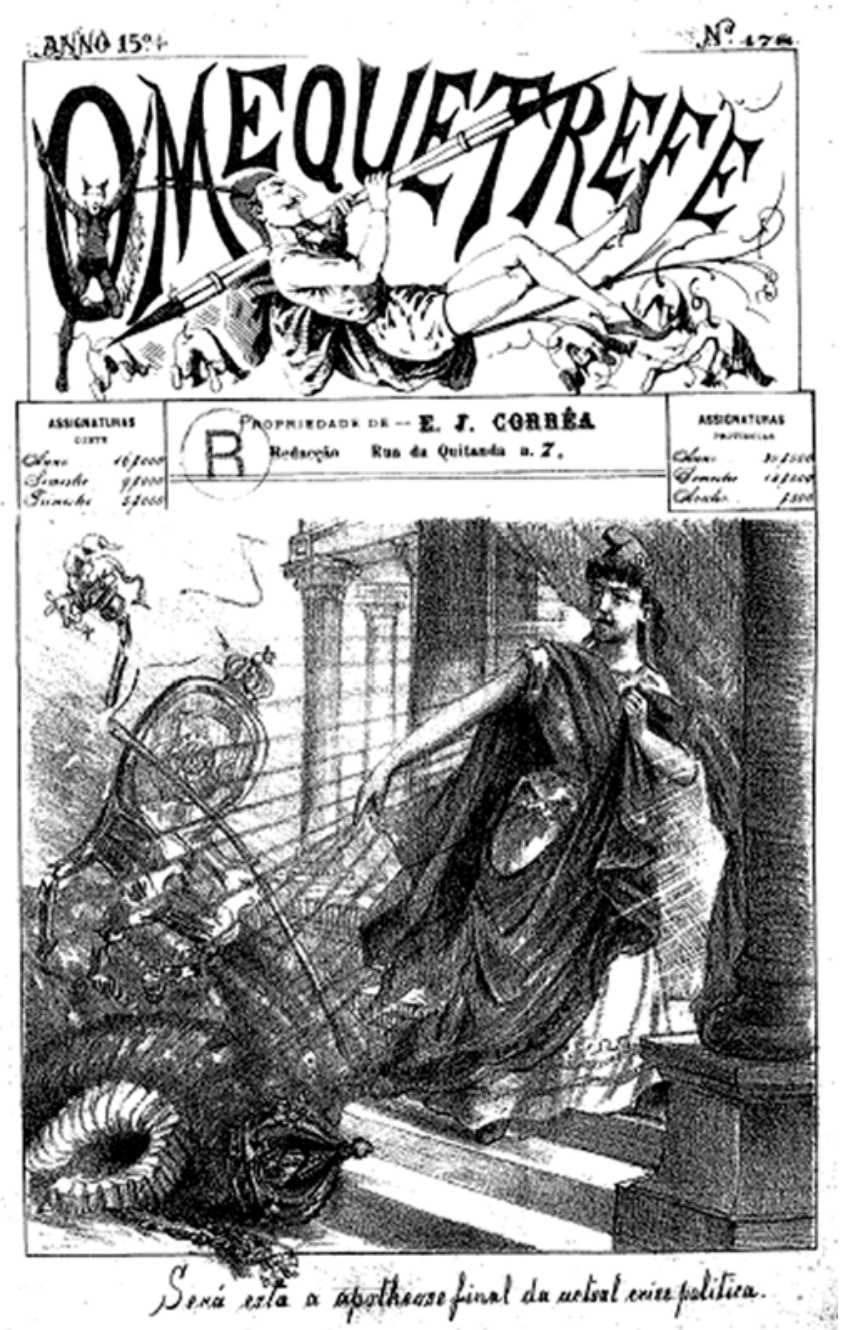

Figura 5: A alegoria feminina e os destroços da Monarquia Legenda: Será esta a apoteose final da atual crise política.

Fonte: O Mequetrefe, Rio de Janeiro, $\mathrm{n}^{\circ}$ 478, p.1, maio de 1889. Acervo: AEL-UNICAMP

Conforme o texto publicado sobre os 15 anos de circulação do jornal, uma das suas bandeiras de luta era a defesa da democracia brasileira, ponto que foi outra vez salientado na ilustração. Para os redatores do periódico, portanto, somente existia uma forma para que a democracia fosse plenamente possível no Brasil, com a instalação de uma República no lugar da destroçada Monarquia. 
“O dia de amanhã”: A República nas páginas do periódico ilustrado

O Mequetrefe, 1875-1889

A democracia foi um ponto ressaltado pelo periódico aparecendo no artigo publicado em janeiro de 1889 e no texto explicativo da ilustração em maio do mesmo ano. Contudo, a qual democracia se referia o jornal? Num primeiro momento, vale considerar que o exercício democrático no Brasil foi limitado desde a Independência, quando a massa de escravos e as camadas pobres e livres da população estavam, por quesito econômico, excluídas do processo político. Já a reforma eleitoral empreendida em 1881 introduziu o voto direto limitado à comprovação de 200 mil réis de renda aos possíveis eleitores, proibiu a participação de analfabetos e manteve a exclusão das mulheres. Assim, a democracia do tempo de circulação do periódico não era plena e sim limitada. Segundo José Murilo de Carvalho (2008) o que limitou o voto foi a exclusão dos analfabetos, uma vez que apenas $20 \%$ da população masculina, única que poderia votar, era alfabetizada eliminando o restante do direito ao voto. O autor cita algumas estatísticas eleitorais, o que demonstra as consequências da lei. Os dados por ele apresentados de 1886, ano mais próximo do texto e da ilustração de $O$ Mequetrefe demonstram que a democracia ainda está longe de ser exercida com plenitude: “Em 1886, votaram nas eleições parlamentares pouco mais de 100 mil eleitores, ou 0,8\% da população total. Houve um corte de quase 90\% do eleitorado” (CARVALHO, 2008, p.38).

“A ideia da democracia brasileira” que "foi sempre por nós sustentada” conforme apregoava o articulista do periódico, provavelmente não era aquela excludente e restritiva, definida pela reforma eleitoral de 1881, porque impedia que uma ampla parcela da população participasse do processo. A noção de democracia no Brasil era outra e não estava relacionada com a Monarquia e sim com a República. O periódico estava passando por um momento de franco combate ao Império em favor da República que, na sua opinião - expressada no texto que explicava a ilustração com os destroços monárquicos - estava relacionada com a defesa da democracia brasileira.

A apoteose republicana ainda não chegaria com a atual crise ministerial uma vez que, no lugar de João Alfredo, foi chamado por Dom Pedro II o conservador Afonso Celso. A mudança na administração imperial foi caracterizada pelo periódico como um insulto “atirado aos brios da nação brasileira, que já começou a levantar-se inspirada nas sublimes doutrinas da democracia” ${ }^{5}$ (Chronica?..., jun. 1889, $\mathrm{n}^{\circ}$ 479, p.2). Na sequência da Crônica, o jornal ressaltava que prováveis tentativas terroristas e despóticas seriam implantadas pela gestão do novo Presidente do Conselho de ministros, na esperança de frear o movimento republicano. A campanha, no entanto, já havia atingido 


\section{Aristeu Elisandro Machado Lopes}

um patamar que seria impossível impedir o seu caminho à vitória: "Não creia o governo que intimidará o movimento republicano, não: a República se fará como se fez a Abolição. Ela não encontrará diante de si obstáculos nem empecilhos: o seu caminhar é sereno e tranquilo” (Chronica?..., jun. 1889, n 479, p.2).

Comemorações à parte, o caminho à apoteose republicana estava mais próximo do que a redação de $O$ Mequetrefe esperava. O número 486, de novembro de 1889, estampava em sua capa a figura do índio recebendo de $O$ Mequetrefe a “Grinalda da Vitória” (Figura 6). O índio foi confeccionado com uma expressão de felicidade, demonstrando a vitória republicana. O arco sem flechas e o escudo colocado apenas como um amparo para ele, indicavam que o novo advento da política no Brasil surgiu pacificamente. Ao empregar a figura do índio, ornado com um barrete frígio, parece que o periódico fazia uma referência à ilustração publicada em suas páginas dez anos antes, aquela do índio que surgiria ressuscitado (Figura 3). O índio renascido em 1879 era a Nação brasileira sob um governo republicano, perspectiva de futuro que somente agora era alcançada. A redação do jornal optou por valorizar dois elementos que foram constantemente empregados em prol da campanha republicana: o índio, como o Brasil e o seu personagem, que significava a luta desencadeada pelo jornal ao longo dos anos.

O advento republicano era o assunto principal da Crônica daquela edição do periódico, e vinha assinado pelas iniciais do sobrenome do seu chefe de redação, José Pinto de Gouveia:

\footnotetext{
Nós, que sempre pugnamos pelo governo da democracia, hoje com a convicção própria de quem sente um peito forte pulsar nobremente, um coração verdadeiramente patriótico, só temos a declarar:

- Acha-se cumprida a nossa missão. Cumprida ela, não devemos parar diante dos atos: prosseguir é nosso dever. Embriagado nessa doce alegria, todo o pessoal da redação d'O Mequetrefe, que há 15 anos lutava pela vitória nobremente ganha no dia 15, não encontrava palavra capaz de exprimir o seu sentimento patriótico que se acha possuído.

E assim terminaremos essa pequenina crônica erguendo um

Viva a República Federal Brasileira! (Chronica..., nov. 1889, nº 486, p.2).
}

A crônica - principal artigo do jornal - sempre veiculada logo após o expediente, assinalava todo empenho desenvolvido por parte do periódico pela República, nos últimos anos. Já o percurso que levou à Proclamação foi narrado num outro texto intitulado “Revolução brasileira de 1889”. A ordem dos textos e das ilustrações demonstra que a redação do periódico optou por privilegiar a sua própria 
“O dia de amanhã”: A República nas páginas do periódico ilustrado

O Mequetrefe, 1875-1889

participação na campanha pela mudança de governo. Em outras palavras, os motivos que desencadearam o advento republicano, promovido por militares e encabeçado por Deodoro da Fonseca, não mereceram a primeira página do jornal.

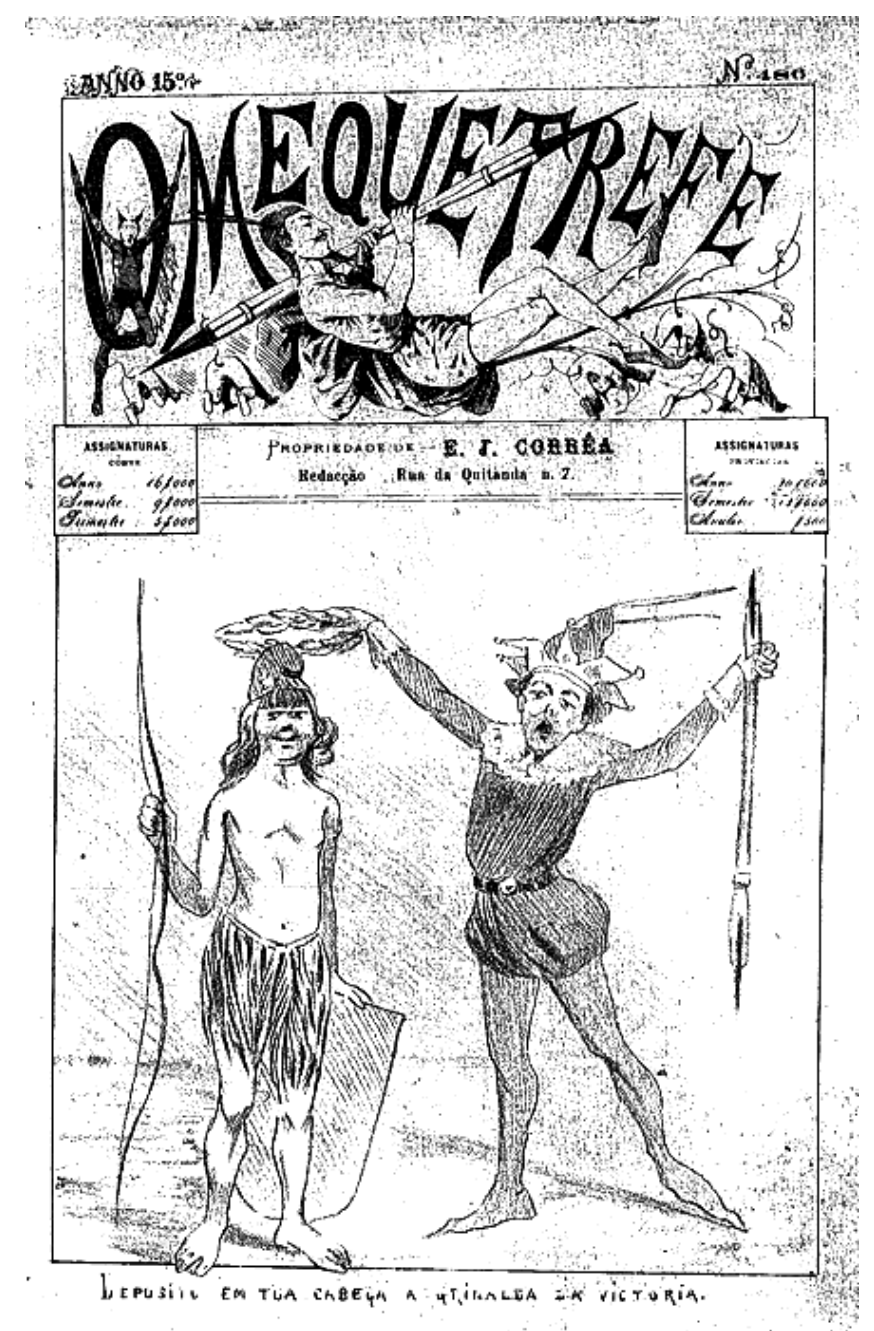

Figura 6: O Mequetrefe e a grinalda da vitória

Legenda: Deposito em tua cabeça a grinalda da vitória.

Fonte: $O$ Mequetrefe, Rio de Janeiro, nº486, p.1, novembro de 1889. Acervo: AEL-UNICAMP

Os militares Deodoro da Fonseca e Benjamin Constant e propagadores republicanos civis como Quintino Bocaiúva, Saldanha Marinho e Campos Salles aparecem nas páginas 4 e 5 desse mesmo número (Figura 7). A ilustração, contudo, também apresenta uma alegoria feminina da República com 


\section{Aristeu Elisandro Machado Lopes}

alguns atributos específicos: a alegoria surge com asas e carrega numa de suas mãos uma tocha, como se estivesse iluminando a ação que há pouco foi desempenhada pelos homens colocados abaixo dela. Numa outra abordagem, o caricaturista poderia remeter ao caminho republicano iluminado por ela e percorrido a partir da Proclamação pelos homens que a realizaram, os quais são os responsáveis pela sua condução. Um dos homenageados pelo periódico é Lopes Trovão, colocado à frente dos demais, e carrega bandeira do clube republicano que leva o seu nome e que seguia o modelo norte-americano ${ }^{6}$.

A primeira página, portanto, não apresentou os responsáveis pelo novo regime e sim o personagem do jornal congratulando o índio, destinando as outras páginas de ilustrações para eles. Distribuindo assim as notícias e ilustrações, o periódico não desconsiderava as atitudes dos responsáveis pela República, porém, tentava se colocar como colaborador no processo que levou à instalação do regime republicano.

É evidente que foi a ação dos militares o principal fator que proporcionou a Proclamação, ficando como coadjuvante a participação de civis; Quintino Bocaiúva declarou, posteriormente, a Proclamação, que tanto Deodoro da Fonseca como Benjamin Constant "desconheciam quase completamente o pessoal político republicano” (CASTRO, 1995, p.175). A aproximação entre os propagandistas republicanos civis e os militares ocorreu dias antes do 15 de novembro; Renato Lemos (1999, p.390) aponta, por exemplo, um encontro entre Benjamin Constant, Mena Barreto e Quintino Bocaiúva, nesta ocasião, o último declarou que se o exército não proclamasse a República o país viveria o $3^{\circ}, 4^{\circ}$ e $5^{\circ}$ reinados. Contudo, ainda que as conversas entre militares e civis tenham acontecido somente nas vésperas da Proclamação, e de maneira moderada, não se deve desconsiderar a atividade propagandista republicana que estava sendo desenvolvida no Brasil. A análise de O Mequetrefe, neste artigo, permitiu verificar que uma das suas bandeiras de luta foi pautada pela atividade republicana e que ela foi iniciada anos antes da efetivação da República. Como os responsáveis pelo periódico não participaram do movimento encabeçado pelos militares, o que lhes restava, além de saudar a República, era tentar se projetar como participantes, embora em menor escala, do caminho que levou à República, o que justifica a primeira página do periódico, sob o novo regime, trazer o seu personagem principal e não um dos proclamadores. 
“O dia de amanhã”: A República nas páginas do periódico ilustrado

O Mequetrefe, 1875-1889

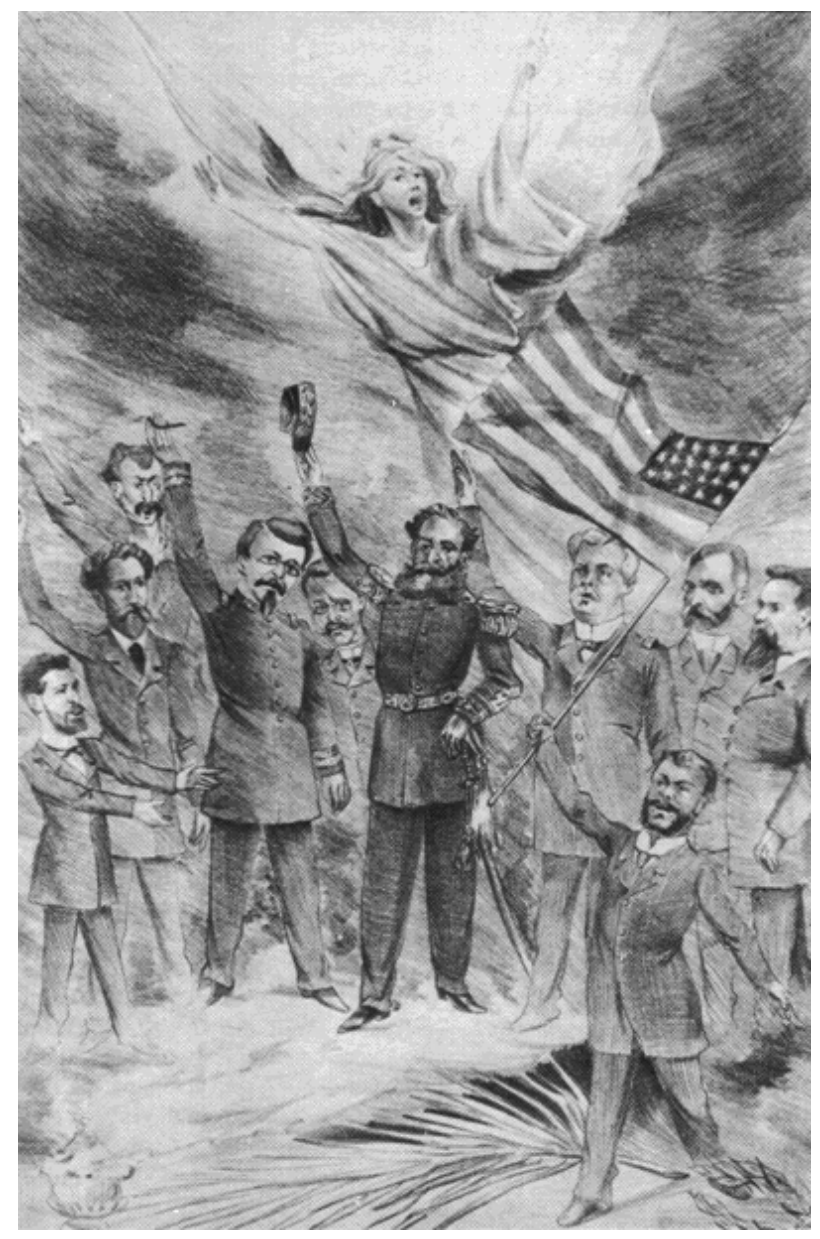

Figura 7: A Proclamação da República

Legenda: Proclamação da República Federal brasileira.15 de novembro de 1889.

Fonte: O Mequetrefe, Rio de Janeiro, $n^{\circ}$ 486, p.1, novembro de 1889. (CARVALHO, 1990, p.83).

\section{Considerações finais}

As ilustrações analisadas ao longo deste artigo são apenas algumas, entre várias outras que circularam em $O$ Mequetrefe e nos demais periódicos ilustrados do Rio de Janeiro, nas últimas décadas do século XIX que trataram da questão republicana. É possível considerar que os desenhos remetem à campanha em prol de um novo governo, ou seja, que ela foi divulgada pelos propagandistas republicanos ainda durante o regime que combatiam, a Monarquia. As ilustrações igualmente demonstram a presença das alegorias femininas nas concepções artísticas dos desenhistas do periódico, as quais serviam para noticiar - ou comentar - as atividades republicanas. No caso específico das 


\section{Aristeu Elisandro Machado Lopes}

ilustrações publicadas em $O$ Mequetrefe, é possível afirmar que as alegorias foram empregadas num tom mais de propaganda, sobretudo nos anos finais do Império, do que aquelas difundidas pelos seus congêneres. Por outro lado, tais alegorias igualmente sugerem que a campanha republicana estava presente nas discussões políticas, as quais sempre figuravam, devido a sua importância, nos desenhos publicados no periódico.

No primeiro desenho, a alegoria feminina foi aproveitada para satirizar o Império e criticar a Igreja Católica. A República, o seu ideal, foi visto pelo caricaturista num tom de apreço e considerada como a única capaz de conceder a liberdade que o Brasil necessitava para alcançar o tão almejado progresso. Na ilustração seguinte, a Alegoria aparece como uma alternativa, caso a “morte” da Monarquia se confirmasse. Já no terceiro desenho, quem surge é o índio, mas ele não é uma representação do Brasil Monárquico, é um Brasil do futuro, republicano, o que se evidencia com o barrete frígio colocado em sua cabeça.

As alegorias seguintes são projeções de uma mudança política a se realizar num momento posterior da história do Brasil. Ambas são confeccionadas com vigor, a primeira numa posição de liderança; a segunda demonstra segurança na remoção dos “destroços da monarquia” numa alusão de que a limpeza não deve ser apenas no palácio, mas no Brasil. A última ilustração analisada encerrava uma parte da história do periódico e destacava a sua atuação na campanha republicana e que o "dia de amanhã”, publicado em 1879 e que se tornaria tão desejado pelo periódico, havia chegado, 10 anos depois, no dia 15 de novembro de 1889.

\section{Notas:}

\footnotetext{
${ }^{1}$ Rafael Bordallo Pinheiro (1846-1905) foi um caricaturista português que ao chegar ao Brasil já tinha alcançado sucesso em Portugal. No Brasil, atuou em O Mosquito a partir de 1875, contudo permaneceu pouco tempo no Brasil retornando para Portugal em 1879. (PINTO, 1915).

${ }^{2}$ Uma reforma religiosa iniciada em meados do século XIX passou a apregoar a doutrina de infalibilidade do Papa, e os seus responsáveis passaram a ser chamados ultramontanos, denominação dada àqueles que defendiam a centralização da Igreja em Roma e no Papa. (VIEIRA, 1980).

${ }^{3}$ Essa ilustração não apresenta uma assinatura ou as iniciais do seu autor, como era comumente usado pelos caricaturistas. No entanto, é provável que a autoria seja de Pereira Netto, visto que ele era o responsável pela parte artística do periódico nesse ano. A mesma informação vale para a ilustração da Figura 4.

${ }^{4}$ Sobre Eugène Delacroix e a tela A Liberdade conduzindo o povo consultar, entre outros, Argan (1992, p.56), Friedlaender (2001).

${ }^{5}$ As “sublimes doutrinas da democracia”, possivelmente se referia à Revolução Francesa, que naquele ano comemorava o seu centenário. Contudo, com a Proclamação da República, as expectativas do periódico não foram alcançadas já que o novo regime manteve o quadro eleitoral inalterado. Novamente, é José Murilo de Carvalho quem aponta esse paradoxo: “A República, de acordo com seus propagandistas, sobretudo aqueles que se inspiravam nos ideias da Revolução Francesa, deveria representar a instauração do governo do país pelo povo, por seus cidadãos, sem a interferência dos privilégios monárquicos. No entanto, apesar das expectativas levantadas entre os que tinham sido excluídos pela lei de 1881, pouca
} 
“O dia de amanhã”: A República nas páginas do periódico ilustrado

O Mequetrefe, 1875-1889

coisa mudou com o novo regime” (CARVALHO, 2008, p.39-40). Os 40 anos que se seguiram à Proclamação, denominados com frequência como "República Oligárquica", não sofreram alterações significativas e denunciaram "um sistema baseado na dominação de uma minoria e na exclusão de uma maioria do processo de participação política” (RESENDE, 2003, p.91).

${ }^{6}$ Sobre a bandeira do Clube Republicano Lopes Trovão e a discussão sobre quais os modelos de bandeiras republicanas, ver: Carvalho (1990, p.109-128).

\section{Referências:}

\section{Fontes:}

14 de Julho. O Mequetrefe, 10 jul. 1883, p. 2.

1889. O Mequetrefe, jan. 1889, $\mathrm{n}^{\circ} 468$, p. 3.

A NOSSA PRIMEIRA página. O Mequetrefe, 07 out. 1875, p. 2.

Chronica? O Mequetrefe, mar.1889, nº 474, p. 2.

Chronica? O Mequetrefe, jun.1889, nº 479, p. 2.

Chronica. O Mequetrefe, nov.1889, nº 486, p. 2.

Galeria Republicana. O Mequetrefe, dez. 1888, nº 466, p. 2.

Homenagem à República Francesa, O Mequetrefe, jul. 1889, nº 481, p. 2.

MARTINS, G. O Mequetrefe, fev.1889, nº 471, p. 3.

O Mequetrefe. O Mequetrefe, jan. 1889, nº 468, p. 2.

O MEQUETREFE ou gato por lebre republicano. O Mequetrefe, 28 out. 1875, p. 3.

O Mequetrefe, 14 jun. 1879, p. 2.

RABELLO, J. J. F. O Mequetrefe, maio 1889, nº 477, p. 2.

\section{Bibliografia:}

AGULHON, M. Marianne au combat. L'imagerie et la symbolique républicaines de 1789 à 1880 . Paris: Flammarion, 1979.

AGULHON, M. Marianne Au pouvoir. L’imagerie et la symbolique républicaines de 1880 à 1914. Paris: Flammarion, 1989. 
Aristeu Elisandro Machado Lopes

ARGAN, G. C. Arte Moderna. Do Iluminismo aos movimentos contemporâneos. São Paulo: Companhia das letras, 1992.

BALABAN, M. Poeta do lápis: A trajetória de Angelo Agostini no Brasil Imperial - São Paulo e Rio de Janeiro - 1864-1888. 2005. Tese (Doutorado em História) - Instituto de Filosofia e Ciências Humanas, Universidade Estadual de Campinas, Campinas, 2005.

BOEHRER, G. C. A. Da Monarquia à República: história do partido republicano no Brasil. Belo Horizonte: Editora Itatiaia, 2000.

CARVALHO, J. M. A Formação das almas. O imaginário da República no Brasil. São Paulo: Companhia das Letras, 1990.

CARVALHO, J. M. Cidadania no Brasil. O longo caminho. 10 ed. Rio de Janeiro: Civilização Brasileira, 2008.

CASTRO, C. Os militares e a República. Um estudo sobre cultura e ação política. Rio de Janeiro: Jorge Zahar Editor, 1995.

DAIBERT JUNIOR, R. Isabel a “Redentora” dos escravos. Bauru: EDUSC/FAPESP, 2004.

FRIEDLAENDER, W. De David a Delacroix. São Paulo: Cosac \& Naify, 2001.

HOBSBAWM, E. A era das revoluções. 1789-1848. 21 ed. Rio de janeiro: Paz e Terra, 2007.

LEMOS, R. Benjamin Constant - Vida e História. Rio de Janeiro: Topbooks, 1999

LIMA, H. Historia da caricatura no Brasil. Rio de Janeiro: José Olympio, 1963.

MELLO, M. T. C. A República Consentida. Cultura democrática e científica do final do Império. Rio de Janeiro: FGV/UFRJ, 2007.

PINTO, M. S. Bordallo e a Caricatura. In: PINHEIRO, R. B. O caricaturista. Lisboa: Livraria Ferreira, 1915, p. 05-49.

RESENDE, M. E. O processo político na Primeira República e o liberalismo oligárquico. In:

FERREIRA, J.; DELGADO, L. A. (Orgs.). O Brasil Republicano. O tempo do liberalismo excludente. Rio de Janeiro: Civilização Brasileira, 2003. vol. 1, p. 91-120.

SALGUEIRO, H. A. A comédia urbana: de Daumier a Porto Alegre. São Paulo: Fundação Armando Álvares Penteado, 2003.

SCHWARCZ, L. M. As Barbas do Imperador. Dom Pedro II, um monarca nos trópicos. 2. ed. São Paulo: Companhia das Letras, 1998.

STAROBINSKI, J. 1789. Os emblemas da razão. São Paulo: Companhia das Letras, 1988. 
“O dia de amanhã”: A República nas páginas do periódico ilustrado

O Mequetrefe, 1875-1889

TEIXEIRA, L. G. S. O traço como texto: a história da charge no Rio de Janeiro de 1860 a 1930 . Rio de Janeiro: Fundação Casa de Rui Barbosa, 2001.

VIEIRA, D. G. O protestantismo, a maçonaria e a questão religiosa no Brasil. Brasília: Editora da UnB, 1980.

VOVELLE, M. Imagens e imaginário na história. São Paulo: Ática, 1997.

Recebido em 28/10/2011

Aprovado em 15/11/2011. 